\title{
A HISTORIOGRAFIA CONSTRUCIONISTA DA ERÓTICA GREGA
}

Daniel Barbo ${ }^{1}$

\begin{abstract}
Resumo
O artigo analisa o olhar pós-moderno e foucaultiano do campo teórico e das metodologias de algumas obras da Historiografia Construcionista que se ocupou com o estudo da erótica grega a partir da década de 1980, tentando revelar seus vínculos com a Nova História Cultural.
\end{abstract}

\section{Palavras-chaves}

Historiografia construcionista, erótica grega, Nova História Cultural, Pósmodernidade, Michel Foucault.

${ }^{1}$ Pós-doutorando, Capes. Universidade Federal de Alagoas - Maceió, AL, Brasil. e-mail: danielbarbo@yahoo.com.br 


\begin{abstract}
The article analyzes the postmodern and foucaultian view of the theoretical field and methodologies of some works of the Constructionist Historiography that engaged with the study of Greek erotic since the 1980s, trying to reveal their ties to the New Cultural History.
\end{abstract}

\title{
Keywords
}

Construcionist historiography, Greek erotic, New Cultural History, Postmodernity, Michel Foucault. 


\section{História e fragmentação}

Em 1990, foram publicadas três obras que inauguraram a abordagem construcionista na convergência da História da Sexualidade e da História Cultural: The constraints of desire: the anthropology of sex and gender in Ancient Greece, de John J. Winkler, One hundred years of homosexuality and other essays on greek love, de David M. Halperin e Before sexuality: the construction of erotic experience in the greek world, editada por David M. Halperin, John J. Winkler e Froma I. Zeitlin. Estas obras foram compostas, em sua maior parte, por artigos escritos pelos respectivos autores (bem como outros, norteamericanos, franceses e ingleses no caso de Before Sexuality) ao longo da década de 1980. A série de ensaios que elas enfeixa emprega posturas teórico-metodológicas em plena compatibilidade com o pensamento de Michel Foucault, especialmente suas teses pós-estruturalistas sobre os comportamentos eróticos no mundo grego antigo ${ }^{2}$. A diversificação nacional dos autores que compuseram essa trilogia dá a medida, por um lado, da extensão do aval ao novo campo teórico-metodológico e, por outro, da pluralidade de contribuições ao estudo renovado do erotismo na Grécia Antiga. Consideramos o empenho comum dessas três obras o representante precursor, portador mesmo de credenciais de movimento fundador, dessa nova abordagem, fértil e em profícua expansão, na historiografia renovada da sexualidade. A importância dessa trilogia como um marco renovador na confluência da História da Sexualidade com a História Cultural foi tematizada por diversos pensadores em muitas resenhas e críticas $^{3}$. Verstraete, comentando a importância do surgimento dessa trilogia, observou que

Devido ao seu escopo abrangente e a originalidade e qualidade de sua erudição, Before Sexuality deve ser acolhido como um trabalho verdadeiramente maior, oferecendo uma cornucópia de insights novos e uma abertura ampla de panorama para pesquisas e reflexões mais profundas. Juntamente com as coleções de Halperin e Winkler e os livros prévios de Foucault e Dover, ele tem preparado a fundação para uma fenomenologia legítima da sexualidade no Mundo Grego antigo. (Verstraete, 1991: 293)

As perspectivas, as metodologias, as matrizes interpretativas fundamentais deste conjunto de obras são tomadas de empréstimo da antropologia cultural, da crítica

${ }^{2}$ Para a argumentação da importância da obra História da Sexualidade de Michel Foucault como uma das bases teóricas mais importantes para a Historiografia Construcionista, a qual vem abordando de forma inovadora a erótica grega desde a década de 1980, cf: Barbo, "Michel Foucault e a Historiografia Construcionista", 2011; Barbo, O triunfo do falo: homoerotismo, dominação, ética e política na Atenas Clássica, 2008.

${ }^{3}$ Cf. Sutton Jr., 1991/1992; Verstraete, 1991; Thorp, 1992; Dover, 1991; Goldhill, 1991; Laipson, 1992. 
feminista, do estruturalismo francês (Verstraete, 1991: 290), bem como da crítica literária. Para analisarmos a matriz historiográfica construcionista, é necessário que se coloque em perspectiva a questão das identidades culturais na Modernidade Tardia. Stuart Hall distingue três concepções muito diferentes de identidade que se sucedem temporalmente: o sujeito do Iluminismo, o sujeito sociológico e o sujeito pós-moderno.

O sujeito do Iluminismo, ou cartesiano, estava baseado numa concepção de pessoa humana dotada de um núcleo interior autônomo e autossuficiente, dotado das capacidades de razão, de consciência e de ação. Embora esse sujeito tenha a capacidade de se desenvolver ao longo da vida, ele permanecia essencialmente o mesmo, contínuo ou 'idêntico' a ele, ao longo de sua existência. Com a crescente complexidade da sociedade moderna, surge a noção de sujeito sociológico, cujo núcleo interior deixa de ser autônomo e autossuficiente, já que sua formação estava na dependência de sua relação com os outros e com o exterior, que mediavam para este sujeito os valores, os sentidos e os símbolos dos mundos que habitava. A interação entre o eu e a sociedade seria a formadora da identidade desse sujeito sociológico.

Esses dois primeiros tipos de sujeito, produtos da Modernidade, são conceituados como tendo uma identidade fixa, essencial ou permanente. A marca fundamental da Modernidade, no que tange às relações entre sujeito e sociedade, era a estabilidade, a fixidez, a unicidade. Hall acredita que exatamente essa relação está se desfazendo como resultado de mudanças estruturais e institucionais características da Modernidade Tardia, isto é, a segunda metade do século $X X^{4}$, especialmente em função do último processo de globalização. Essas mudanças estão deslocando e fragmentado (ou 'pluralizando') as identidades, colocando em colapso a estabilidade, a fixidez e a unicidade da relação moderna entre sujeito e estrutura. O processo de identificação, com o qual nos projetamos em nossas identidades culturais, está se tornando cada vez mais provisório, variável e problemático, uma vez que o sujeito pós-moderno está sendo visto como "composto não de uma única, mas de várias identidades, algumas vezes contraditórias ou não resolvidas". Portanto, o sujeito pós-moderno é

\footnotetext{
${ }^{4}$ HALL, 2006, p. 34-46, aponta cinco grandes avanços na teoria social e nas ciências humanas ocorridos no pensamento, ou que sobre ele tiveram seu principal impacto, no período da modernidade tardia, tendo como maior efeito o descentramento final das noções que vêem o sujeito racional e a identidade como fixos e estáveis (isto é, a morte do sujeito cartesiano): i) a releitura do marxismo pelo estruturalismo de Louis Althusser; ii) a releitura da descoberta freudiana do inconsciente por pensadores psicanalíticos como Lacan; iii) a linguística estrutural de Ferdinand de Saussure; iv) a 'genealogia do sujeito moderno' do filósofo e historiador francês Michel Foucault; v) o nascimento histórico na década de 1960 da política de identidade, tanto como crítica teórica quanto como movimento social, com a qual cada movimento apelava para a identidade social de seus sustentadores: "o feminismo apelava às mulheres, a política sexual aos gays e lésbicas, as lutas raciais aos negros, o movimento antibelicista aos pacifistas, e assim por diante".
} 
conceituado, na visão de muitos pensadores, como não tendo uma identidade fixa, essencial ou permanente (Hall, 2006: 10-12). Esta obra de Hall, mapeia

as mudanças conceituais através das quais, de acordo com alguns teóricos, o 'sujeito' do Iluminismo, visto como tendo uma identidade fixa e estável, foi descentrado, resultando nas identidades abertas, contraditórias, inacabadas, fragmentadas, do sujeito pós-moderno. (Hall, 2006: 46)

Com essas mudanças estruturais e institucionais das últimas décadas, provocadoras de descentralizações, deslocamentos, desestruturações e fragmentações na identidade do sujeito e em sua relação com a estrutura, o que configura, para muitos pensadores, as novas condições da pós-modernidade,

o sujeito assume identidades diferentes em diferentes momentos, identidades que não são unificadas ao redor de um "eu" coerente. Dentro de nós há identidades contraditórias, empurrando em diferentes direções, de tal modo que nossas identificações estão sendo continuamente deslocadas. Se sentimos que temos uma identidade unificada desde o nascimento até a morte é apenas porque construímos uma cômoda estória sobre nós mesmos ou uma confortadora "narrativa do eu". A identidade plenamente unificada, completa, segura e coerente é uma fantasia. Ao invés disso, na medida em que os sistemas de significação e representação cultural se multiplicam, somos confrontados por uma multiplicidade desconcertante e cambiante de identidades possíveis, com cada uma das quais poderíamos nos identificar ao menos temporariamente. (Hall, 2006: 13)

Em tais condições, em que "a pós-modernidade desconstrói, deslegitima, deslembra, desmemoriza o discurso da 'Razão que governa o mundo' " (Reis, 2003: 73), Reis afirma que "o ser é diferença constante, isto é, temporal e inessencial, e aparece em linguagens múltiplas. Sem pronunciar o ser, as linguagens múltiplas o constituem transitório e diferente..." (Reis, 2003: 73).

A nova abordagem da História Cultural está estreitamente vinculada a essa visão da mutação da relação do sujeito com a estrutura, bem como da mutação do próprio sujeito, mutações que criaram novas bases para o estatuto do conhecimento histórico e para a escrita historiográfica. O percurso intelectual, filosófico, conceitual e historiográfico que explica a sexualidade como uma construção cultural emerge dessas mutações que nos levam à condição pós-moderna.

Seguindo a análise de Reis, verificamos que essa mutação no estatuto da história e na escrita historiográfica - fruto da transmutação do sujeito e das novas relações que se estabelecem entre sujeito e estrutura, especialmente no processo de globalização - está claramente evidenciada pela passagem que se verifica entre a história global (do século 
XIX à segunda geração dos Annales) e a história em migalhas (a terceira geração dos Annales) ${ }^{5}$. A história cultural parece ser o empreendimento intelectual mais bem sucedido nesse processo de esmigalhamento da história. Reis contabiliza as perdas e os ganhos que a nova forma de se perceber o real e a temporalidade e de se escrever a história representa e, considerando os prós e os contras, enumera algumas características dessa transição ou ruptura. Seguiremos essas características, tentando ler atentamente a análise de Reis, para evidenciar o tom pós-moderno da historiografia construcionista e, portanto, sua plena conformidade com a história cultural. Consideramos que os processos descritos por Hall e Reis, ligeiramente expostos aqui, sobrepõem-se, recobrem-se e são, por conseguinte, complementares. Ou, antes, perfazem as duas faces de Jano, passado e futuro, de um processo múltiplo. Descrevem, no conjunto, a mutação do moderno ao pós-moderno, da história global à história em migalhas, nos âmbitos teórico, historiográfico, conceitual, do sujeito e da relação do sujeito com a estrutura, o que sinaliza as condições pós-modernas da escrita historiográfica da história cultural.

Pensando na esfera das identidades eróticas, então, uma constatação possível a partir da observação da transição da história global à história em migalhas descrita por Reis no nível macroteórico, historiográfico e conceitual, e do processo descrito por Hall, processo que este autor condensa e sistematiza a partir de vários autores (A. Giddens, D. Harvey, E. Laclau) e é relatado aqui de forma muito esquemática - qual seja, a transmutação do sujeito, e, portanto, das identidades no desenrolar da modernidade e da modernidade tardia - é a afirmação de que, se a historiografia essencialista do homoerotismo grego está calcada na concepção de sujeito cartesiano (sujeito do Iluminismo e/ou sujeito sociológico) ${ }^{6}$, a historiografia construcionista reflete já (ou remete-nos para) uma concepção de sujeito pós-moderno, comprometida, nesse sentido, com a chamada Nova História Cultural. Partindo de diferentes concepções de sujeitos e de diferentes interações entre sujeitos e estruturas, cada uma dessas matrizes historiográficas produz discursos particulares e diversificados ao estabelecer uma relação dialética entre as categorias eróticas do mundo grego antigo e as categorias eróticas da modernidade e da pós-modernidade. Lugar comum: as narrativas históricas, os produtos da escrita da história e as tendências historiográficas prendemse inexoravelmente às temporalidades ou, nas palavras de Koselleck, aos tempos históricos. Constatamos, portanto, que a historiografia essencialista está vinculada à modernidade, ao passo que a historiografia construcionista está vinculada à pósmodernidade. E entre elas há diferenças profundas, pois, em função da vitória, nas

${ }^{5}$ Cf. Reis, 2003, especialmente Capítulo 2: Da história global à história em migalhas: o que se ganha, o que se perde?

${ }^{6}$ Cf: Barbo, D. "Detratores do homoerotismo grego: uma historiografia essencialista". 
últimas décadas, do individualismo capitalista globalizante, acelera-se a fragmentação do sujeito (das identidades) e da escrita histórica (História em migalhas); o historiador vê-se na impossibilidade de falar do todo, de uma História Global, totalizante (a ilusão do universal), mas quer falar de tudo (fragmentação extrema tendente à incongruência e à perda da especificidade lógica da história); e o sentido da história (a ilusão das filosofias da história) esvazia-se cada vez mais (que horizonte de expectativa se pode esperar de histórias fragmentadas, desconectadas? $\mathrm{O}$ horizonte da diversidade multifragmentada?).

Entretanto, quando defendemos o argumento de que a narrativa da historiografia construcionista seja uma das produções da história cultural das últimas décadas do século XX, e, portanto, estreitamente vinculada aos complexos deslocamentos provocados pelo mundo pós-moderno, ou, melhor dizendo, uma narrativa que fala a partir da pós-modernidade, não consideramos que os autores construcionistas se alinhem, de forma alguma, em termos de narratividade da história, a "uma posição relativista à Hayden White, que não vê no discurso de história senão um livre jogo de figuras retóricas, senão uma expressão dentre outras da invenção ficcional." (Chartier, 2002: 15) Concordamos plenamente com Roger Chartier (e também, num outro registro metodológico, com Carlo Ginzburg) que recomenda - contra essa dissolução do estatuto de conhecimento da história produzida por obras como as de White e que frequentemente é considerada nos Estados Unidos como uma figura do pósmodernismo - "sustentar com força que a história é comandada por uma intenção e por um princípio de verdade, que o passado que ela estabelece como objeto é uma realidade exterior ao discurso, e que seu conhecimento pode ser controlado." (Chartier, 2002: 15)

As lutas pelas liberdades sexuais em torno de construções de identidades eróticas, identidades multiplicadas, perfazem uma das facetas dessas mudanças sociais, dessas mutações históricas e historiográficas. Nesse processo, Stonewall, guardadas as devidas proporções, teve o efeito de uma "Revolução Francesa" para essas lutas: sua propagação sísmica acelerou o movimento pluralizador de identidades; contribuiu com a produção da fragmentação dos sujeitos. Evidencia-se, então, o impacto desse acontecimento e de seus desdobramentos diversos sobre a nova escrita da história da sexualidade, cristalizada naquilo que se autodenominou construcionismo.

\section{A vocação pós-moderna da historiografia construcionista}

1. Antes da Sexualidade 
Um dos principais articuladores da abordagem construcionista, David Halperin, em sua obra One Hundred years of homosexuality and other essays on greek love, considera esse novo enfoque um posicionamento diante das relações entre práticas sociais e cultura que avança, em relação à tendência essencialista, na análise das expressões, dos comportamentos e das experiências eróticas na história ao repensar e resignificar a constituição da 'sexualidade' na Modernidade e redefini-la enquanto categoria de análise operativa para a História da Sexualidade e ao propor o método intitulado 'poética cultural do desejo' para a análise da construção das experiências e dos comportamentos eróticos na história. Ao aprofundar o debate sobre a articulação entre categorias eróticas e a cultura na qual elas emergem, ou seja, a determinação cultural de categorias eróticas, a abordagem construcionista está principalmente preocupada com a construção dos significados eróticos em cada sociedade e em cada cultura. Somente no mundo moderno ocidental essa construção é articulada pelas categorias da 'sexualidade'. Como compreender a construção desses significados nas sociedades que não instituíram a 'sexualidade'? A obra Before sexuality, tratando dessa construção no mundo grego antigo, aponta uma metodologia: a 'poética cultural do desejo'.

Os ensaios reunidos nessa obra combinam duas tradições intelectuais. Neles, mesclamse as preocupações teórico-metodológicas específicas da prática francesa denominada les sciences humaines, com seu olho ávido na semiótica e nas estruturas profundas, e os procedimentos descritivos e interpretativos desenvolvidos na tradição anglo-americana da antropologia cultural. (Halperin; Winkler; Zeitlin, 1990: 7) Desse cruzamento, nascem as técnicas da 'poética cultural do desejo'.

Esta metodologia trata o campo erótico de uma dada sociedade, não enquanto uma instância isolada e autônoma da realidade social, como poderia ensejar um enfoque que se baseasse numa categoria de análise unitária e datada como a 'sexualidade', mas enquanto uma instância na qual estão implicados vários outros aspectos culturais e campos sociais daquela sociedade. Os idealizadores dessa metodologia afirmam que múltiplos significados da vida erótica, em qualquer sociedade, só são inteligíveis se tomados em relação ao todo do tecido social. Por essa forma, os vários autores dos ensaios que compõem a obra Before sexuality não estudam os aspectos da erótica na Antiguidade grega como se esses aspectos formassem um assunto à parte, como se a erótica fosse uma variável independente, cujos tremores e vicissitudes pudessem ser descritos numa narrativa linear e coerente com mínima referência às outras áreas de interesse humano. (Halperin; Winkler; Zeitlin, 1990: 3)

Esses autores, historiadores da cultura, redefinem conceitualmente a categoria 'sexualidade'. Nessa nova definição, 'sexualidade' deixa de ser pensada como uma categoria de análise unitária, essencialista, e passa a ser pensada como uma das linguagens para definir, descrever, interpretar e negociar todas as condutas, modos, valores e perspectivas dos outros campos culturais da sociedade. Ela torna-se uma área 
de discussão na qual interagem muitos projetos sociais diferentes, como, por exemplo, matrimônio, política, trabalhos domésticos, herança, educação. A sexualidade passa a ser pensada como uma instância social que sofre mudanças. (Halperin; Winkler; Zeitlin, 1990: 4). Sob essa nova perspectiva, então, ainda poderíamos chamar esse campo de estudo de História da Sexualidade. Mas somente a partir da perspectiva mais ampla e profunda da interação social, dessa rede de mutualidade que são os processos sociais de construção de significados, será possível compreender de forma mais acurada o modo como acontece a construção dos significados eróticos nas diversas sociedades. Segundo esses novos idealizadores do construcionismo, essa compreensão pode ser atingida por meio da noção de 'poética cultural do desejo'. Primeiramente, vejamos o que esses autores chamam de 'poética cultural'. Ela refere-se

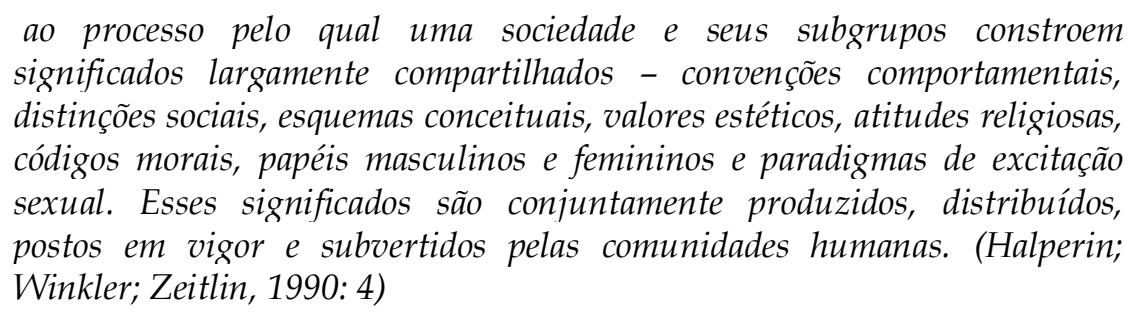

Esse processo mais amplo de construção de significados culturais inclui a formação de identidades eróticas. Afirmando a interdependência cultural entre práticas sociais e experiências subjetivas, a abordagem construcionista pode falar, então, de uma 'poética cultural do desejo': “as experiências eróticas dos indivíduos, são, assim, do nosso ponto de vista, artefatos que refletem, em parte, a poética cultural mais ampla das sociedades nas quais aqueles indivíduos vivem." (Halperin; Winkler; Zeitlin, 1990: 4)

A 'poética cultural do desejo' é, pois, uma parte da 'poética cultural' total de uma sociedade. A abordagem construcionista, então, procura compreender a formação das identidades eróticas de uma dada sociedade através da investigação da 'poética cultural do desejo' em processo naquela sociedade. Os ensaios contidos na obra Before sexuality seguem essa linha de análise e trazem à tona a multiplicidade de concepções, por vezes incompatíveis, que moldavam as práticas e as experiências fundamentais da vida erótica na Antiguidade grega. A tônica dessa obra, a construção das experiências eróticas gregas, tornou-se, na medida em que era investigada, um território vasto de inúmeras possibilidades. Explorando diferentes discursos e comportamentos eróticos, a obra mostra uma parte significativa da diversidade erótica na Antiguidade e um conjunto de possíveis evidências disponíveis para estudo. Vistos sob esse novo prisma, os gregos antigos tinham muitos modos diferentes de falar e agir em relação às questões eróticas, muitas estratégias de desvelamento ou ocultação, de representação ou supressão. A obra Before sexuality reflete essa diversidade ao apresentar alguns exemplos dos trabalhos que estão sendo feitos nesse campo. 
Verstraete notava, em 1991, que "Before Sexuality abriga material literário, epigráfico e iconográfico dificilmente ou não totalmente integrado até agora ao estudo do sexo e do gênero no mundo grego antigo." (Verstraete, 1991: 292) Os quinze artigos que compõem Before Sexuality, privilegiando então fontes gregas negligenciadas, exploram dimensões simbólicas para transcender a sexualidade enquanto tema. Nessa complexa obra, os artigos dos autores franceses disponibilizam uma gama de evidências iconográficas: The sexual life of satyrs, de François Lissarrague, mostra que as extravagâncias semihumanas dos sátiros retratadas nos vasos áticos expressam normas para o comportamento sexual humano; From Ambiguity to Ambivalence: A Dionysiac Excursion through the 'Anakreontic' Vases, de Françoise Frontisi-Ducroux e François Lissarrague, explica os komoi 'anacreonticos' retratados em vasos como uma mediação dionisíaca da desordem causada pela 'estranheza/alteridade', através de sinais de feminilidade e exterioridade. Este artigo possui a mais detalhada erudição iconográfica na coleção e chega a uma convincente interpretação estruturalista das figuras masculinas andróginas em algumas cenas de komoi na pintura de vasos gregos; Aspects of Baubo: Ancient Texts and Contexts, de Maurice Olender, examina figurinos e textos sobre Baubo, uma figura genital obscena e humorística que funde a sexualidade feminina com as nutridoras e assustadoras afetações das velhas enfermeiras. (Sutton Jr., 1991/1992: 190; Verstraete, 1991: 292)

The Future of Dreams: From Freud to Artemidorus, de S. R. F. Price, compara as análises de sonhos de Artemidoro e Freud. O artigo de Price compartilha solo comum com o de Winkler, Unnatural Acts, o primeiro de sua obra The Constraints of Desire. Ambos mostram que a interpretação dinâmico-sexual dos sonhos não tem contrapartida na oneirocrítica da Grécia Antiga, a qual estava em grande parte preocupada com a explicação da saúde e do status político futuros do sonhador, ao ponto de que até mesmo a simbologia sexual dos sonhos era decodificada nos limites dessa estrutura de predição. The Semiotics of Gender: Physiognomy and SelfFashioning in the Second Century C.E., de Maud W. Gleason, examina estereótipos de gêneros em textos fisiognômicos e astrológicos para descobrir regras que decodificam o comportamento criptografado do homem efeminado (cinaedus). A antiga pseudociência da fisiognomia sobreviveu no Ocidente até bem depois da Renascença. Se The Medical Writers' Woman, de Ann Ellis Hanson, um artigo que faz uso de uma literatura médica e ginecológica, demonstra que ginecologias antigas reconheciam o hímen, já Maidenhood without Maidenhead: The Female Body in Ancient Greece, de Giulia Sissa, argumenta o contrário, posto que tal evidência tangível era desconsiderada em favor de sinais mais confiáveis da virgindade. $\mathrm{O}$ artigo de Sissa combina a literatura médica e ginecológica com outras fontes antigas, tais como a mitologia, a história e a etnografia. 
The Poetics of Eros: Nature, Art, and Imitation in Longus' Daphnis and Chloe, de Froma I. Zeitlin, vê o tratamento de eros em Daphnis \& Chloe como uma peça sofisticada por meio das familiares dicotomias natureza/cultura e arte/vida. From Sex to Politics: The Rites of Artemis Triklaria and Dionysos Aisymnetes at Patras, de James Redfield, considera que um complexo mítico-ritual em Patras envolvendo Ártemis e Dioniso coloca a política como a resposta para os problemas do sexo. Putting Her in Her place: Woman, Dirt, and Desire, de Anne Carson, descobre, em textos que descrevem as mulheres como sendo úmidas, selvagens, vazantes e poluidoras, uma concepção de feminilidade como um ilimitado perigoso na carência de contenção, a qual seria providenciada pelo casamento e pelo véu. Novamente, como em sua obra Eros the bittersweet: an Essay, de 1986, Carson apresenta uma análise aguda e penetrante, embora continue a ignorar os escritos feministas, que poderiam relativizar a misoginia grega. Herakles: The Super-Male and the Feminine, de Nicole Loraux, considera elementos masculinos e femininos contraditórios no herói Heracles, pondo em foco particularmente sua barriga, sua túnica e sua relação com Hera. One... Two... Three...: Eros, de Jean-Pierre Vernant, considera eros como mediação entre a pessoa e os outros, a respeito de Platão, Dioniso, Narciso e Plotino. Bodies and Minds: Sexuality and Renunciation in Early Christianity, de Peter Brown, descreve novos alinhamentos entre a pessoa, o sexo e a sociedade que surgiram com o Cristianismo. O artigo de Brown é uma incisiva recapitulação das principais teses de sua obra The Body and Society de 1988. (Sutton Jr., 1991/1992: 190; Verstraete, 1991: 292)

O que se percebe, também, nesses artigos, é tanto uma prática da especialização em detrimento da síntese quanto uma prática da descrição/constatação/relativismo em detrimento da explicação/conceito. Seguindo ainda a análise de Reis, podemos constatar que os autores de Before Sexuality

consideram impossível compatibilizar olhar global com estudo
cientificamente conduzido; [...] defendem a história-problema, que só pode
controlar o seu objeto se o delimita ao máximo; [...] consideram que só se
pode formular um problema controlável e uma hipótese sustentável e
elaborar uma documentação diversa e suficiente se houver uma
especialização por parte do historiador, pois não se pode conhecer
cientificamente o todo, só a parte. (Reis, 2003: 92)

[...] desconfiam de uma ciência globalizante, que seria uma contradição, pois $o$ discurso científico se autocontrola evitando a abordagem total $e$ delimitando, limitando, assumindo um relativismo moderado, o que só é possivel na fragmentação e na especialização. (Reis, 2003: 93)

2. Os constrangimentos do desejo

Em sua obra The Constraints of Desire: The Anthropology of Sex and Gender in Ancient Greece, publicada em 1990, John J. Winkler sustenta que as mulheres-cidadãs gregas, de um modo geral, possuíam um grau de autonomia muito maior que os protocolos sociais, 
referendados pelos discursos públicos prescritivos masculinos ${ }^{7}$, fizeram aos investigadores do mundo grego antigo supor. Estes protocolos ou as premissas usualmente tácitas "que governam a força das declarações públicas, e parece que grande parte da conversa fiada dos homens sobre as mulheres e sobre si mesmos" (Winkler, 1994: 16) - isto é, o androcentrismo - eram, diz Winkler, uma farsa calculada. Os elementos fundamentais destes protocolos consistem em que:

o contato sexual é entendido nos contextos públicos como iniciado pelo varão, falocentrado e estruturado em torno do ato da penetração; todos os atos que se conformam com esses protocolos são relativamente não-problemáticos (katá nomon); os únicos atos que se podia supor um horror geral são o incesto e o contato oral-genital; e, por último, há um pressuposto implícito de que a identidade sexual não organiza a pessoa, posto que seja periférica aos objetivos e às preocupações centrais, que se concentram na sobrevivência, no status público, na manipulação em busca de um lugar nas hierarquias sociais às expensas dos outros competidores, na estabilidade e na prosperidade das famílias patriarcais num ambiente hostil. (Winkler, 1994: 56)

Havia, portanto, no que se refere à condição de liberdade e autonomia dessas mulheres-cidadãs em relação aos homens, uma grande distância entre os protocolos androcêntricos e a realidade social. "Eram as mulheres gregas antigas (o que usualmente quer dizer as da Atenas Clássica) tratadas apenas como algo melhor que um escravo ou tinham um lugar honorável, respeitado e protegido na sociedade?" (Winkler, 1994: 15)

Winkler constata que a asserção mais comum na historiografia moderna de uma submissão feminina tão generalizada no mundo grego pode ser relativizada a partir da leitura de trechos de obras de alguns autores como Longo, Homero e Safo, posto que

[...] a convenção do androcentrismo é uma linguagem limitada dos homens em certas condições; não representa de maneira adequada todo o mundo social, como gostaríamos de descrevê-lo, mas antes serve melhor para demarcar uma área restrita de importância (a das transações públicas) e para falar dela em termos absolutos como se se tratasse da totalidade. [...] $O$ androcentrismo mediterrâneo é tanto uma verdade inquestionável como uma mentira universal. (Winkler, 1994: 17).

Demarcar o que Winkler chama de protocolos androcêntricos é pôr em evidência um campo representacional do mundo grego que articula os três registros de realidade, enunciados por Chartier, no que diz respeito ao domínio do erótico e do gênero com

\footnotetext{
${ }^{7}$ Winkler. Laying down the law: the oversight of men's sexual behavior in classical Athens. In: Halperin; Winkler; Zeitlin, 1990. Neste ensaio, Winkler argumenta que "as convenções sociais e editoriais dentro das quais tinha lugar a maior parte dos discursos orais públicos e dos escritos publicados tendiam a dar voz a um grupo seleto de cidadãos adultos do sexo masculino e a emudecer os outros - mulheres, adolescentes, metecos”, p. 173.
} 
plena referência ao espaço público e à política, verificando a sua validade e seu escopo de abrangência, decodificando o alcance de sua verdade e seu fundo ficcional. A verificação dessa constatação perpassa os artigos reunidos nessa obra de Winkler, que, dividida em duas partes (Andres e Günaikes), tem como pontos centrais alguns aspectos do sexo e do gênero na Grécia Antiga analisados sob uma perspectiva antropológica. A instrumentação metodológica adquirida pelo autor com as técnicas da antropologia social e cultural, particularmente como as praticam as feministas, indica-o um modo para se fazer uma análise mais rica e completa do sexo e do gênero nas sociedades da Grécia Antiga, para além do que nos podem informar, a respeito destes temas, os protocolos detectados em obras de vários autores gregos. Também, os estudos feminista e gay são referências utilizadas para a compreensão de "que as sociedades passadas podem ser estudadas não por seu valor para fazer uma observação política a respeito do presente, mas por sua diferença cabal e surpreendente" (Winkler, 1994: 15). Procurando responder à pergunta o que é História Cultural?, Peter Burke faz uma pequena consideração a respeito da obra The Constraints of Desire, incluindo Winkler no rol dos novos historiadores culturais. Sobre um dos resultados da obra, Burke diz:

No caso da Grécia Antiga, um classicista inspirado pela antropologia cultural, John Winkler, mostrou que, embora as fontes sobreviventes sejam quase inteiramente resultado do trabalho de homens, elas podem ser vistas sob a ótica contrária, revelando pontos de vista claramente femininos sobre sexo e outros assuntos. Ele trata a lírica de Safo e o festival feminino de Adonia como evidencias particularmente valiosas de "uma consciência, por parte das mulheres gregas, no que se refere ao significado de sexo e gênero diferentes dos enunciados por seus maridos e pais". (Burke, 2005: 41)

O projeto de analisar as construções culturais de gênero e de sexo leva Winkler à questão da construção cultural de identidades na história. A respeito do estudo da sexualidade, Winkler repropõe as perguntas de Rosalind Coward:

Por que, quando aparece nas ciências sociais, o estudo da sexualidade é com frequência subsumido em estudos de formas (sociais) institucionalizadas da regulação sexual, como o matrimônio? Por que não há uma teoria das formas de dominação e desigualdade na dinâmica das relações sexuais? Por que não há uma compreensão da construção da identidade sexual ou uma consideração do poder e do status que essa identidade poderia entranhar? (Winkler, 1994: 15-16)

Em The Constraints of Desire, Winkler evita para o conjunto dos ensaios qualquer tipo de enfoque unificador que tenda à simplificação. Antes, deixa os ensaios seguirem sua própria lógica para que, em conjunto, possam reproduzir a diversidade de perspectivas e experiências, o que entra em harmonia com a sua intuição de que

[...] tanto o enfoque da história das ideias como o estruturalista não logram, de certo modo, fazer justiça a seu objeto. O primeiro não capta as práticas das pessoas reais, incluindo os intelectuais, ao passo que o segundo, com sua 
ênfase no sistema e na regularidade, passa por alto pelo debate e pelo conflito de uma sociedade com múltiplos centros de autoridade e um elevado sentido da ilusão/fraude e do tácito. (Winkler, 1994: 23)

A divisão do livro nas partes Andrés e Günaikes e a sequência dos sete ensaios e dos apêndices seguem uma lógica que se relaciona com as especificidades das identidades sexuais e de gênero nas sociedades gregas. No primeiro artigo, 'Atos antinaturais: protocolos eróticos na análise dos sonhos de Artemidoro', a obra deste autor grego guia Winkler na análise dos protocolos do androcentrismo, do alocentrismo e da invasão, posto que Artemidoro ${ }^{8}$ é para Winkler a melhor testemunha da verificação de que "de todos os significados e facetas do comportamento sexual que poderiam ser singularizados para oferecer-lhes uma atenção especial, os gregos se concentraram insistentemente na dominação e na submissão, tal como as constitui a penetração fálica." (Winkler, 1994: 23) Winkler faz certas afirmações acerca do social tanto para caracterizar os protocolos fundamentais como para mostrar os limites de sua aplicação às vidas reais. Ao propor essa estratégia, o autor, naturalmente, recusa-se a reconstruir a história cultural do sexo simples ou primordialmente em termos de ideias, mas nos termos das práticas sociais em conflito. Para tanto, nesse enfoque antropológico, ele "[...] usa A interpretação dos Sonhos (Oneirocritica) de Artemidoro para por em relevo os princípios básicos dos significados empregados pelos homens de fala grega da Bacia Mediterrânea na Antiguidade para interpretar os atos sexuais." (Winkler, 1994: 32)

Como introdução a sua análise da obra de Artemidoro, Winkler identifica a faceta cultural disfarçada naquilo que muitos autores gregos e latinos chamam de 'natureza' ao falar de sexo. Como ele próprio diz ao analisar certas passagens: "onde se diz natureza, leia-se cultura" (Winkler, 1994: 29). Ou seja, Winkler alerta que nos discursos produzidos por estes autores sobre o sexo, o que eles consideravam natural ou atribuíam à natureza era, na realidade, cultural, não-universal, datado, "convencional e apropriado" (Winkler, 1994: 29). Sendo assim, nos contextos de comportamento humano, 'antinatural' geralmente significa 'seriamente anticonvencional', demarcando territórios morais. O próprio contraste phüsis/nomos ou natureza/cultura, um produto do empreendimento sofístico do século $\mathrm{V}$ a.C.,

[...] é em si mesmo um elemento cultural, uma forma de pensamento descoberta recentemente, que daí de preferência se estendeu e finalmente foi utilizada como arma em uma luta cultural historicamente específica (hoje

8 Artemidoro Efésio ou Artemidoro Daldiano foi um adivinho profissional do século II d.C. É conhecido por sua famosa obra, em cinco volumes, intitulada Oneirocritica (A Interpretação dos Sonhos). Segundo Artemidoro, parte do material de sua obra fora recolhida de diversos adivinhos que encontrava durante suas longas viagens pela Grécia, Península Itálica e Ásia. Outras fontes foram os seus predecessores, dos quais dezesseis são nominalmente citados em sua obra. 
chamada de Ilustração) [...] isto significa dizer que ainda que nos pareça natural discutir sobre o sexo em termos de natureza e 'antinatureza', a 'naturalidade' dessas categorias é, em si mesmas, uma espécie de ilusão cultural. Como a sexualidade, a 'natureza' (segundo se aplica ao sexo) tem uma história. (Winkler, 1994: 30)

Entre os vários exemplos deste tipo de discurso no mundo grego que Winkler investiga para desmistificar o "natural", decodificando o seu lastro "cultural", temos um exemplo nas Leis de Platão, as quais, segundo o historiador, parecem inaugurar as condenações às práticas da pederastia:

O porta-voz de Platão nas Leis (835B-842A) joga com a ideia de inventar uma ordem social que se conformasse com a 'natureza' como a sociedade grega supunha que ela fosse antes de o pai de Édipo, Laio, inventar a pederastia. Fazer isso exigiria uma reestruturação massiva das crenças e práticas comuns, colocando a pederastia em pé de igualdade com o incesto, para que todo mundo sentisse horror por ela. O legislador de Platão confessa que sua ideia é um sonho impossível. Ainda que este sonho, ou melhor, pesadelo, se realizasse - e o fizesse nos mesmos termos empregados nas Leis, vindo a pederastia a ser estigmatizada como "antinatural" - o que deveria se destacar a respeito do texto de Platão é o desespero sentido nele acerca do impossivel, quase a inconcebilidade, do projeto. Tratava-se claramente de uma ideia-experimento da mesma ordem que a censura à poesia tradicional na República e que estava completamente na contramão dos valores, práticas e debates da sociedade de Platão. Essas especulações de Platão são pouco representativas - não o movimento de abertura em um novo jogo para moralizar o sexo - e, portanto, somente obliquamente útil para escrever a história dos costumes e das práticas sexuais de uma sociedade. (Winkler, 1994: 30-31)

Há analogias entre a interpretação artemidoriana e a freudiana, pondo-as em uma interessante relação de espelho. Ambas dividem a mente humana em consciência e inconsciência. Ambas consideram os sonhos como atividades naturais da psükhé e os sonhos consistem em colocar um véu sobre sentimentos significativos mediante a condensação e o deslocamento a uma linguagem simbólica cujos elementos são extraídos das associações imediatas do sonhador. Divergem, no entanto, em dois pontos fundamentais.

Em primeiro lugar, na interpretação artemidoriana, a ação da alma no sonho tem como alvo o futuro próximo do sonhador. A mente inconsciente conhece as mudanças transcendentais que estão prestes a suceder. A função do intérprete (Artemidoro) é ajudar o sonhador a fazer uma leitura do conteúdo onírico premonitório. Já na interpretação freudiana, o alvo é o passado distante do sonhador. A mente inconsciente é assediada pelos fatos remotos da infância. A função do intérprete (Freud) é ajudar o sonhador a compreender ou encarar os estados emocionais internos. 
Em segundo lugar, embora em ambos os sistemas as teorias da estrutura, o funcionamento da alma e as práticas de entrevistas aos clientes sejam semelhantes, há uma grande diferença no valor culturalmente determinado que se atribui ao sexo. (Winkler, 1994: 39-43)

A Oneirocritica põe continuamente em exibição supostos sociais comuns e mostra o funcionamento dos protocolos androcêntricos e de outros baseados no sexo e no gênero, mas se mantendo exterior a eles, escapando, assim, das limitações impostas pelas inclinações habituais dos textos moralistas ou elitistas de um Platão, um Dion ou um Filon. Winkler considera que a teoria e a prática da obra de Artemidoro, diferentemente das obras dos moralistas e dos elitistas, estão livres dos preconceitos e tendências que comumente estão presentes em qualquer autor antigo que transmita e avalie informações sociais. "A postura empírica de Artemidoro permite-nos captar uma semântica geral do sexo no mundo antigo, costumeiramente obscurecida pelo tratamento tendencioso dos moralistas" (Winkler, 1994: 56). A obra tem um valor enorme para reconstruir os parâmetros da prática sexual antiga porque sua categorização dos atos sexuais, de ampla difusão e muito perduráveis, corresponde à percepção pública do significado do comportamento sexual, desde que:

O traço mais importante do sistema interpretativo de Artemidoro é seu princípio operativo de que os símbolos $e$ as associações de um sonho codificado são extraídos, pela alma, da própria experiência cultural do sonhador, não de um Livro de Significados universal ou da linguagem dos deuses. O fato de que sonhos filologicamente sofisticados somente aparecem em pessoas educadas é uma prova a mais de que "[os] óneiroi são obra da alma e não provêem de nada exterior". (Winkler, 1994: 41)

Na maioria dos casos, à parte os sonhos únicos e individuais, encontra-se naturalmente confrontado todo o espectro de associações e avaliações comuns e públicas, o que faz dela [Oneirocritica] uma excelente fonte de informação sobre a vida cotidiana no mundo antigo. (Winkler, 1994: 43)

Sendo assim, um intérprete de sonhos como Artemidoro, para o sucesso de sua profissão, deve conhecer os costumes, a cultura, os códigos simbólicos dos povos a que pertencem seus clientes. Ou seja, deve ser um observador-participante, posto que Artemidoro, "como um antropólogo, compartilha da vida das pessoas que investiga, tratando simultaneamente de se meter em seus sentimentos e comportamentos e também de se colocar fora deles" (Winkler, 1994: 43). Esse axioma interpretativo requer que o intérprete distinga dentre as convenções (ethe) as que são universais das que são específicas de uma cultura local. Assim,

Os trácios que sonham com tatuagens dizem algo diferente do que dizem os getas que sonham com o mesmo, dado que entre aqueles a tatuagem é um sinal de nascimento nobre, enquanto que entre os getas é um signo de escravidão. (Winkler, 1994: 41) 
Requer também que o intérprete conheça as especificidades da identidade de cada sonhador, seja a riqueza, o status social e conjugal, a ocupação, a saúde, a idade e coisas semelhantes. O significado de 'transformar-se numa ponte', em sonhos, varia de acordo com a identidade do sonhador. Segundo a interpretação de Artemidoro:

Alguém sonhou que se transformava numa ponte: passou a ser barqueiro, cumprindo a mesma função que uma ponte... Todavia, um homem rico sonhou que se transformava numa ponte: muitos o desprezaram e, desse modo, foi (por assim dizer) pisoteado. Se alguma vez uma mulher ou um belo jovem tem este sonho, tornar-se-ão prostitutas [/os] e receberão muitos sobre si. Um homem comprometido em um pleito judicial que tenha este sonho elevar-se-á acima de seus adversários e do próprio juiz, posto que o rio seja como um juiz, enquanto faz o que quer com impunidade, mas uma ponte está por cima do rio. (Winkler, 1994: 42)

Fica claro que essa investigação de Winkler coaduna-se perfeitamente com a postura da escrita da história nos moldes da historiografia pós-moderna, forjada sob a urgência e a regência do sujeito pós-moderno. Noutro exemplo,

[...] o cunnilingus e a felatio entre marido e mulher são ocorrências oníricas terrivelmente nefastas, mas não para dois homens determinados, conhecidos de Artemidoro, a quem simplesmente agradavam essas práticas. "Simplesmente viam o que os excitavam." (Winkler, 1994: 42)

Seguindo as interpretações de Artemidoro, o que interessa a Winkler é explorar "o axioma de que as imagens oníricas são determinadas em princípio pelas próprias experiências e associações contingentes do indivíduo, mais que por conexões universais ou divinas estabelecidas há muito tempo" (Winkler, 1994: 42). Interessa-lhe investigar a diversidade das identidades culturais do mundo grego, sob a perspectiva da fragmentação identitária (método da Antropologia Cultural em face da nova realidade sociocultural surgida após a década de 1960), que escapa aos protocolos androcêntricos, e não as ilusórias estruturas universais que falam muito mais das ideias culturalmente impostas por elites que do real vivido. A obra de Artemidoro lhe permitiu tal empreendimento teórico-metodológico:

Essa prolongada discussão dos métodos e princípios de Artemidoro foi necessária para lançar os fundamentos de minha leitura de suas afirmações acerca dos acontecimentos sexuais nos sonhos. O valor de seu texto para nós depende de nossa compreensão de que ele representa não somente a opinião de um homem acerca dos protocolos sexuais das sociedades antigas, mas também uma coleção incalculável de evidências - uma espécie de Relatório Kinsey da antiguidade -, baseado em milhares de entrevistas de clientes. (Winkler, 1994: 46)

Winkler aceita a proposição de Foucault (História da Sexualidade) de que os esquemas de avaliação geralmente aceitos descritos no Oneirocritica, obra do século II d.C., "estão muito próximos dos princípios gerais que já no período clássico organizavam a 
experiência moral da aphrodisia. O livro de Artemidoro é, portanto, um marco. Dá testemunho de um esquema de pensamento que tinha larga vigência e era corrente em sua época" (Foucault apud Winkler, 1994: 57). O historiador norte-americano tira algumas grandes conclusões, a partir desse estudo da Oneirocritica, em relação à esfera erótica do mundo grego antigo do século II d.C., as quais formam, assim, as bases para a análise do comportamento sexual dos homens feita no artigo subsequente intitulado 'Ditando a lei: a vigilância do comportamento sexual dos homens na Atenas Clássica'.

Primeiro, a Oneirocritica possui uma vasta gama de informações sobre a percepção dos significados públicos da atividade sexual. O ofício de Artemidoro, enquanto um antropólogo dos significados oníricos, estabelecendo uma postura empírica diante da substância dos sonhos premonitórios de seus clientes, permite-o - em suas interpretações dos símbolos numa operação ventríloqua entre significantes e significados - tanto evidenciar a consistência e o alcance dos protocolos androcêntricos, quanto escapar destes, ao rejeitar os juízos de valor e as preconcepções que Winkler denuncia nos autores moralistas e elitistas/intelectualistas. Segundo, ao operar com a categoria "natureza", a obra evidencia mais uma vez o que Winkler já havia identificado e analisado em outros autores gregos, isto é, "natureza", para os autores gregos citados que expressam contextos sobre sexo, quer dizer "cultura". Os protocolos fundamentais que determinam o campo de significação do sexo são vistos pelos autores gregos como fazendo parte da "natureza". Esta "supõe que o que é significativo na atividade sexual é (i) os homens, (ii) os pênis que penetram e (iii) com isto, a articulação dos status relativos através de relações de dominação. [...] Uma vez mais, 'natureza' resulta significar 'cultura' " (Winkler, 1994: 52-53). Entretanto, afirma Winkler:

Artermidoro usa a palavra "natureza" não como um juizo de valor, mas como um termo categórico para assinalar um limite importante neste campo da significação social. Por "antinatural" entende simplesmente que certos atos são impossíveis ou irrelevantes, ou seja, não são significativos dentro dos termos do significado social do sexo. Assim, a seu próprio modo, ilustra mais uma vez o tema de que "natureza" quer dizer "cultura", mas com a interessante peculiaridade de que cultura (sua "natureza") inclui tanto o convencional (katá nomon) como o anticonvencional (pará nomon), já que ambas as categorias formam parte do "natural" (katá phüsin). (Winkler, 1994: 56)

Tendo em mente essas conclusões gerais, Winkler, no artigo Ditando a lei, propõe-se a examinar as operações sociais mediante as quais o desvio em relação aos protocolos androcêntricos se articulou, se inspecionou e se manejou, no que se refere ao comportamento sexual dos homens nas camadas mais elevadas da cidadania ateniense entre os anos 430 e 330 a.C., tendo como foco o funcionamento cotidiano da comunidade e em particular suas práticas de autocontrole. (Winkler, 1994: 59) 
Para tanto, Winkler faz um levantamento das várias imagens culturais da virilidade correta e incorreta expressas no caráter agonístico da esfera pública ateniense ${ }^{9}$. Ali, ele analisa, fundamentalmente, os limites da aplicação nas práticas sociais de uma convenção característica dessa esfera pública: a competição soma-zero no sistema de moralidade honra/vergonha ${ }^{10}$ nas disputas e debates públicos. (Winkler, 1994: 61) Essa competitividade pública tem como um de seus parâmetros a ideologia hoplites $\mathrm{x}$ kínaidos. O hoplites e o kínaidos são as personificações, respectivamente positiva e negativa, dos protocolos fundamentais. Essa polarização revela a representação da masculinidade na tensão entre o comportamento positivo da figura do hoplítes (soldado-cidadão com posses o suficiente para obter a panóplia) e o comportamento negativo da figura do kínaidos (imagem poderosa de um homem cujo comportamento social e erótico era desviante na medida em que violava a definição social dominante de masculinidade idealizada na figura do hoplítes). Enquanto o hoplítes é a representação da masculinidade ideal que todo cidadão em busca de honra almeja, o kínaidos, sempre vítima de troça, zombaria ou indignação, é a representação da efeminização pavorosa que constantemente ronda a reputação desse cidadão, quando quer que ele comece a perder seu próprio equilíbrio moral. (Winkler, 1994: 59-60)

Contra um exército inimigo na guerra, o espírito de solidariedade prevalecia entre os soldados atenienses. Mas, dentro da pólis, a competição entre os cidadãos no espaço público podia ser atroz, particularmente entre os mais influentes, os mais empreendedores, os mais conspícuos e os mais jovens. E as competições políticas e jurídicas nesses espaços públicos, seja na ágora, na assembleia ou nos tribunais, organizavam-se de acordo com os mesmos cânones de virilidade, bravura e altivez expressos pelo ideal de masculinidade do hoplites em guerra contra o inimigo. Como propõe Winkler, a rinha ou briga de galos, uma atividade muito praticada na Atenas Clássica, é uma metáfora bem apropriada para representar as disputas nas altas rodas do espaço público da democracia ateniense. O conjunto dos discursos forenses de

\footnotetext{
${ }^{9}$ A constituição ateniense previa auditorias rigorosas (dokimasía e dokimasía rhetoron) das contas e atos dos funcionários públicos ao final do ano de ofício, dando ampla oportunidade a qualquer cidadão para fazer acusações contra qualquer ato de sua administração. Essas oportunidades eram constantemente usadas pelos inimigos políticos para ataques maliciosos e chantagens. Esse é o caso, por exemplo, da própria acusação que Ésquines fez contra Timarco, embora ele não considere a si próprio um sicofanta (sykophántes): "eu tenho me mostrado um homem modesto e tranquilo." [Ésquines, Contra Timarco, 1]. A leitura de uma peça jurídica como o Contra Timarco revela a amplitude e o teor da feroz competitividade forense em Atenas ao longo do século IV a. C.

${ }^{10}$ Winkler afirma que entre os atenienses "a compreensão cultural da competição não era simplesmente a de que os vencedores ganhavam recompensas e honra, mas, também, a de que os perdedores eram estigmatizados com vergonha e penalidades em quantidades proporcionais", p. 178. E acrescenta que "a luta de galos era uma representação supremamente clara da competição soma zero". Winkler. Laying down the law: the oversight of men's sexual behavior in classical Athens. In: Halperin; Winkler; Zeitlin, 1990 , p. 181 , nota 28 .
} 
Ésquines e Demóstenes, por exemplo, ilustra muito bem essa agressividade necessária num ambiente de democracia direta. Para sobreviver nesse ambiente, um cidadão deveria demonstrar uma virilidade hoplítica.

Um cidadão poderia ser acusado de abandonar as suas responsabilidades tanto por um escrutínio público movido pelo Estado, quanto por um processo iniciado privadamente. Dentre essas responsabilidades, nos quadros desse sistema de imagens culturais em vigor nas discussões públicas sobre o comportamento apropriado de um soldado-cidadão, prescrevia-se, no que se refere ao comportamento erótico, uma conduta moral estabelecida como adequada à virilidade hoplítica. Mas as leis referentes à moralidade erótica eram formuladas não em termos de desvio efeminizante (katápygon, eurýproktos, kínaidos), o qual não era, como tal, acionável juridicamente nos tribunais atenienses, mas em termos de prostituição (hetairekós, pórnos, peporneuménos). A acusação de prostituição, como no caso de Timarco, formalizava-se em três componentes não claramente discerníveis num ato efeminizante: promiscuidade, venalidade e passividade à penetração fálica.

Somente os cidadãos mais influentes no gerenciamento político do Estado, no entanto, costumavam empregar tais recursos jurídicos, os quais eram usados como armas para derrubar seus oponentes na arena pública. Essa pequena elite considerava-se a representante dos mais altos níveis de masculinidade. Principalmente para um homem desse grupo de cidadãos, a não exibição de bravura (andreía) proporcionava-lhe um rebaixamento simbólico de sua masculinidade que podia remetê-lo à classe oposta das mulheres. (Winkler, 1994: 60)

Nesse sentido, a virilidade dos cidadãos encontra-se sempre à prova em competições públicas, corrend o o perigo constante de resvalar para o servil ou para o feminino. Por um lado, o masculino e o feminino não participam de uma oposição simples, como os dois lados de uma moeda. Entre eles, há um continuum que pode ser atravessado, como num arco-íris. Uma gradação que parte do hoplites, passa pelas várias nuances da efeminização, pelas categorias da prostituição, e chega ao polo mais inferior da escala da cidadania: a mulher. Por outro lado, a identidade feminina não é somente um oposto da identidade masculina. É também a sua constante ameaça. Essa polaridade fundamental entre o homem e a mulher instaura uma polaridade inframasculina traduzida pelos contrastes hoplítes $\mathrm{x}$ kínaidos e cidadão politicamente ativo (politeuómenos) versus prostituto (hetairekós, pórnos, pepornéumenos). O contraste entre o hoplítes e o kínaidos reflete uma polaridade mais fundamental que os gregos estabeleceram entre homens e mulheres. Isto é, a polaridade cultural entre os gêneros age internamente em um deles, criando um conjunto de polaridades inframasculinas entre o hoplítes e o kínaidos. Essa observação da reversibilidade da pessoa masculina no mundo antigo, ameaçando-lhe constantemente com o perigo de deslizar para o servil 
ou o feminino, tinha já sido advertida por Stephen Greenblatt ${ }^{11} \mathrm{em}$ sua obra Fiction and Friction. (Winkler, 1994: 65)

Essa imagem cultural da virilidade hoplítica prescreve para o homem a necessidade de exercer os desejos de uma forma em que se demonstre domínio sobre si e sobre os outros. Desde que a atividade erótica é um ato simbólico da competição soma-zero, o hoplítes quer dominar e o kínaidos quer ser dominado. De acordo com a polarização penetrador e penetrado, supunha-se que a figura do kínaidos expressava o desejo de ser penetrado, o que assimilava essa figura ao papel feminino. (Winkler, 1994: 67)

Portanto, a altivez de uma masculinidade moldada na função bélica era um elemento fundamental da honra na alta competitividade política dos escalões superiores da vida pública ateniense. Para derrubar um adversário público, valia conspurcar a sua vida privada e o seu comportamento erótico, justamente como fez Ésquines em sua acusação contra Timarco, e como fez muitos outros retores, oradores e cidadãos politicamente ativos. O orador Ésquines atesta essa prática explicitamente: "[...] o que é frequentemente dito sobre os processos públicos não é mentira, a saber, que muitas inimizades privadas corrigem abusos públicos." (Aeschines, Against Timarchus, 2)

Nessa análise das imagens culturais sob as quais o comportamento sexual dos homens está submetido a uma constante vigilância no âmbito da esfera pública ateniense, Winkler adverte a que distância o ideal de erómenos, o parceiro mais jovem da relação pederástica, se encontra tanto das categorias da prostituição masculina quanto da imagem cultural do kínaidos:

Estamos evidentemente, em um âmbito diferente do da procura romântica de varões adolescentes por parte de homens jovens dentre vinte e trinta anos, conhecida como pederastia, uma atividade bem ilustrada nos vasos atenienses de fins do século VI e começos do V e retratada nos diálogos platônicos como uma experiência às vezes sofrível, às vezes deliciosa, mas sempre de interesse $\mathrm{e}$ aprovação geral. Na pederastia, como demonstraram cuidadosamente Dover [Greek Homosexuality], Golden [Pais, Child and Slave] e Foucault [The History of sexuality: The Use of Pleasure], combinavam-se várias convenções para proteger o membro menor do par do estigma da efeminização, de ser um kínaidos. (Winkler, 1994: 68)

${ }^{11} \mathrm{O}$ crítico literário e teórico norte-americano Stephen Greenblatt é considerado por muitos um dos fundadores do New Historicism, um conjunto de práticas críticas que ele próprio refere como Poética Cultural. 
A relação pederástica (erastés/erómenos) encontra-se, é claro, intimamente articulada com essas imagens culturais. Por ela, perpassam os mecanismos da estratégia desse jogo sociopolítico estruturado pelos protocolos androcêntricos na medida em que (i) $\mathrm{O}$ erómenos, enquanto politeuómenos (cidadão politicamente ativo) em potencial, participa, em tese, de uma relação pedagógica; (ii) $\mathrm{O}$ comportamento erótico dos cidadãos masculinos em geral, mas em especial o do politeuómenos e do jovem, estão em constante vigilância sob a ideologia hoplites x kínaidos; (iii) A relação erótica entre erastés e erómenos, se, por um lado, deve preservar a masculinidade do erómenos, por outro, reproduz as relações de poder sociopolítico.

Descortina-se, então, a simbologia social e o caráter de representação coletiva dos protocolos, o que o impele a garimpar discursividades que lhe possibilita repensar as margens de autonomia feminina e revelar pontos de vista femininos sobre sexo e outros assuntos numa sociedade androcêntrica/falocêntrica à beira, em alguns recantos discursivos gregos, da misoginia. A História Cultural e a Crítica Literária exigem-lhe que decodifique em verdade incontestável e mentira universal as estratégias representacionais que balizam e vigiam os comportamentos sexuais dos cidadãos atenienses da alta esfera pública em suas imagens culturais: a ideologia hoplítes x kínaidos, a competição soma zero, a moralidade honra/vergonha e a inframasculinidade. A condição do sujeito pós-moderno, obsedado por identidades múltiplas e contraditórias em variáveis deslocamentos, move o seu interesse em direção à diversidade identitária em seu fluxo entre o real e o idealizado, imaginado, representado no próprio mundo grego: erastés, erómenos, hoplítes, kínaidos, hetairekós, pórnos, pepornéumenos, identidades eróticas visualizadas agora num descentramento ignorado pela visão essencialista que miopemente enxergava homossexualidade e heterossexualidade na Grécia Antiga e que estava impossibilitada de pensar a alteridade. Desmascarar pressupostos naturais sobre sexo e gênero como sendo profundamente culturais - onde se diz natural, leia-se cultura - é um empreendimento da História Cultural. E é com esse mesmo olhar antropológico que ele pode analisar a pederastia ateniense, isto é, a relação erastés/erómenos, em sua especificidade, em sua alteridade, demarcando as suas profundas diferenças em relação à categoria moderna da homossexualidade.

\section{Cem anos de homossexualidade}

Retomando a tese foucaultiana da construção da sexualidade, os ensaios contidos na obra One hundred years of homosexuality de David M. Halperin gravitam em torno do tema da erótica da cultura masculina na antiguidade clássica, em particular, no mundo grego antigo. O objetivo fundamental da obra é

[...] examinar mais intimamente os vários aspectos pelos quais as práticas sexuais gregas diferem das 'nossas próprias' [...] e conceber uma interpretação das experiências eróticas na antiguidade clássica que coloque 
em primeiro plano a especificidade histórica e cultural daquelas experiências. (Halperin, 1990: 1-2)

Em termos macroteóricos, a rejeição de uma história global (a não totalidade) e a tônica posta na fragmentação (o não sistema) já se enunciam no prefácio da obra. Estes ensaios, diz Halperin,

não constituem um tratamento compreensivo e sistemático daquele (grande) tópico [a erótica da cultura masculina no mundo grego antigo]. Antes, eles focam aspectos selecionados deste e exploram uma variedade de questões que emergiram dos esforços modernos para elucidá-lo. (Halperin, 1990: ix)

A obra não possui um ensaio exclusivo sobre a pederastia ateniense, ainda que dela o autor faça uma brilhante análise. Antes, Halperin inquire

os componentes e contextos sociais mais amplos do 'Amor Grego', acreditando que nós possamos chegar a um entendimento mais satisfatório da pederastia ateniense clássica se não a virmos como uma instituição isolada, e portanto 'queer', mas se a considerarmos, de preferência, como meramente um fio numa rede maior e mais intricada de práticas eróticas e sociais na Grécia Antiga, que variam da amizade heróica ao sexo comercial. O resultado dessa mudança de ênfase, eu espero, será o de ampliar o escopo do estudo da erótica da cultura masculina na Grécia antiga, e de distanciar este estudo da moderna categoria médico/forense/social-científica da homossexualidade. (Halperin, 1990: ix)

A obra está dividida em duas partes: os ensaios da primeira parte [1. One Hundred Years of Homosexuality; 2. 'Homosexuality: A Cultural Construct (An Exchange with Richard Schneider); 3. Two Views of Greek Love: Harald Patzer and Michel Foucault] são, em grande medida, teóricos e remetem para um número de questões relacionadas com o método erudito e a prática crítica corrente. Os da segunda [4. Heroes and their Pals; 5. The democratic body: Prostitution and Citizenship in Classical Athens; 6 . Why is Diotima a Woman?], são exemplos de crítica literária prática e análise histórica que ampliam alguns dos princípios contidos nos ensaios anteriores para uma série de problemas concretos na interpretação da cultura grega. (Halperin, 1990: 9)

No primeiro ensaio, One Hundred Years of Homosexuality, Halperin investiga o surgimento dos neologismos "homossexual" e "homossexualidade" no século XIX, demonstrando que o termo mais comumente usado naquele século para se referir ao contato erótico entre pessoas do mesmo sexo ou ao comportamento desviante de gênero, isto é, "inversão sexual", não denotava o mesmo fenômeno conceitual que "homossexualidade". Segundo Halperin, de acordo com o estudo da literatura médica sobre o assunto feito por George Chauncey em 1982-83,

'Inversão sexual' referia-se a uma larga variedade de comportamentos desviantes de gênero da qual o desejo homossexual era somente um aspecto 
lógico, mas indistinto, ao passo que 'homossexualidade' focava-se na questão mais limitada da escolha de objeto sexual. A diferenciação do desejo homossexual dos comportamentos 'desviantes' de gênero na virada do século reflete uma reconceitualização maior da natureza da sexualidade humana, sua relação com o gênero e seu papel na definição social do indivíduo. (Chancey apud Halperin, 1990: 15)

A verificação de tal reconceitualização, da "inversão sexual" à "homossexualidade", que explora e põe em relevo a formação de subjetividades e de identidades eróticas, remete-nos à preocupação da História Cultural em colocar em primeiro plano na escrita histórica não mais a estrutura, mas o indivíduo, não mais o social objetivo, mas o individual subjetivo. O que reflete o descrédito, para a historiografia vinculada às mudanças pós-modernas, das abstrações estruturais, desencarnadas e irreais; a consideração como "reais", indivíduos concretos e singulares; a valorização da subjetividade e do tendencioso, por representarem manifestações do indivíduo e não terem mais a pretensão do claro e do distinto universal. (Reis, 2003: 93)

Para Halperin, a evidência dos múltiplos fenômenos eróticos examinados no corpus documental grego vem confirmar a tese foucaultiana de que as identidades eróticas são socialmente construídas, além de fornecer um campo instigante de investigação para a História da Sexualidade, fundamentalmente no que diz respeito às relações eróticas entre pessoas de mesmo sexo, o que proporcionou os novos avanços alcançados pela historiografia construcionista. Na sequência do capítulo One Hundred Years of Homosexuality, o autor elabora uma primeira argumentação nesse sentido ao refutar a tese fundamental das obras de John Boswell, a tese de que as identidades eróticas são essências humanas, e, portanto, tendem à universalidade e à naturalidade.

Por essa via de raciocínio, mesmo bem antes de surgir o termo homossexualidade, existia já a sua prática e identidade, da mesma forma como a gravidade já era experimentada antes de 1685, ano em que Isaac Newton formulou a Lei da Gravitação Universal. Boswell afirmou que a proposta do famoso mito de Aristófanes relatado no Banquete platônico "é explicar porque os seres humanos são divididos em grupos de interesse predominantemente homossexual ou heterossexual". Portanto, para este autor, este mito, juntamente com vários outros da Antiguidade Clássica, garantiria a existência da homossexualidade e da heterossexualidade enquanto categorias eróticas antigas (senão universais) da experiência humana. A sua interpretação do mito leva-o a concluir que, de acordo com o Aristófanes platônico, interesses homossexuais e heterossexuais são "tanto exclusivos quanto inatos". (Halperin, 1990: 18-19)

A argumentação de Halperin para refutar essa tese de Boswell é convincente. Ela desconstrói a ideia de que pudesse haver na cultura grega algum indício de que os gregos compartilhassem qualquer noção que fosse remotamente semelhante ao que hoje podemos chamar de homo e heterossexualidade. Halperin defende a ideia de que 
não se pode concluir tal divisão a partir deste mito já que, das consequências dele, o próprio Aristófanes não apontara aquela conclusão. Pelo contrário, este mito ajuda a ilustrar o quanto os atenienses clássicos desejavam evitar conceituar comportamentos sexuais em acordo com uma oposição binária que polarizasse contatos sexuais entre pessoas de mesmo sexo e contatos sexuais entre pessoas de sexo oposto. Os contra-argumentos são dois:

Em primeiro lugar, o mito de Aristófanes gera não duas, mas pelo menos três "sexualidades" distintas (homens atraídos por homens, mulheres atraídas por mulheres, e - consignadas igualmente em uma única classificação, evidentemente - homens atraídos por mulheres, bem como mulheres atraídas por homens). Além do mais, não há a mais leve sugestão, em nada que Aristófanes diz, de que os atos ou preferências sexuais de pessoas descendentes de um original feminino sejam de algum modo similar aos, sem falar congruente com ou isomórfico aos, atos e preferências sexuais daqueles descendentes de um original masculino. Daí que nada no texto permite-nos suspeitar da existência mesmo de uma categoria implícita à qual pertençam tanto homens que desejam homens quanto mulheres que desejam mulheres em contradição a alguma outra categoria contendo homens e mulheres que desejam um ao outro. (Halperin, 1990: 19-20)

Por esse modo de analisar o mito, a sua consequência é o de perceber o desejo sexual de todos os seres humanos como formalmente idênticos: todos os humanos estariam procurando "um substituto simbólico para um objeto originário uma vez amado e subsequentemente perdido num trauma arcaico." Nesse sentido, todos os humanos pertencem a uma mesma "sexualidade" e, dessa forma, ninguém é individualizado ao nível do ser sexual. (Halperin, 1990: 20)

Em segundo lugar, e contrariando as implicações claras do mito expostas acima, o relato de Aristófanes, argumenta Halperin, "figura uma distinção dentro da categoria de homens que são atraídos por homens, um detalhe infraestrutural que não consta na descrição de cada uma das outras duas categorias". Halperin refere-se às características fundamentais da pederastia grega, isto é, à condição de que tal homem é um paiderastes (o adulto que ama o jovem) e um philerastes (o jovem que é receptivo ao adulto) em diferentes momentos de sua vida, bem como às diferenças que caracterizam as "sexualidades" de cada uma dessas categorias ${ }^{12}$. Assim,

diferentemente das pessoas que integram as duas primeiras categorias, aqueles que descendem de um masculino original não atraem um ao outro sem qualificação; Pelo contrário, eles desejam garotos quando são homens e

12 Para uma análise mais ampla das diferenças entre as categorias paiderastes e philerastes, ver Halperin, 1990, nota 31 do capítulo One hundred years of homosexuality; Barbo, 2008, capítulo 3: O homoerotismo na cultura falocêntrica. 
obtêm um certo prazer (não-sexual) no contato físico com homens, quando são garotos. Então, desde que - como a passagem prévia sugere - os atenienses clássicos distinguiam claramente os papéis de paiderastes e philerastes, relegando-os não somente a diferentes classes de idade, mas virtualmente a diferentes "sexualidades", o que Aristófanes está descrevendo aqui não é uma orientação sexual homogênea e única comum a todos aqueles que descendem de um masculino original, mas antes um conjunto de comportamentos distintos e incomensuráveis os quais tais pessoas exibem em períodos diferentes de suas vidas [...]. (Halperin, 1990: 20)

Representações de distinções identitárias num mito num diálogo filosófico... Representação é um conceito-chave para a história cultural. Roger Chartier, um autor definitivamente associado à Nova História Cultural pensa que a importância deste conceito está em permitir

articular três registros de realidade: por um lado, as representações coletivas que incorporam nos indivíduos as divisões do mundo social e organizam os esquemas de percepção a partir dos quais eles classificam, julgam e agem; por outro, as formas de exibição e de estilização da identidade que pretendem ver reconhecida; enfim, a delegação a representantes (indivíduos particulares, instituições, instâncias abstratas) da coerência e da estabilidade da identidade assim afirmada. A história da construção das identidades sociais encontra-se assim transformada em uma história das relações simbólicas de força. Essa história define a construção do mundo social como o êxito (ou o fracasso) do trabalho que os grupos efetuam sobre si mesmos - e sobre os outros - para transformar as propriedades objetivas que são comuns a seus membros em uma pertença percebida, mostrada, reconhecida (ou negada). Consequentemente, ela compreende a dominação simbólica como o processo pelo qual os dominados aceitam ou rejeitam as identidades impostas que visam a assegurar e perpetuar seu assujeitamento. (Chartier, 2002: 11)

As identidades eróticas são socialmente construídas e suas representações codificam-se na diversidade dos produtos culturais. Em relação ao mito analisado, Halperin evidencia esses registros de realidade articulados por meio das representações, ao afirmar que "a imagem desenhada pelo Aristófanes de Platão é uma representação historicamente precisa das convenções morais que governam o comportamento sexual na Atenas Clássica, senão da realidade do próprio comportamento sexual." (Halperin, 1990: nota 31)

Halperin estabelece alguns pontos básicos a respeito do ato erótico na Atenas Clássica. Sinteticamente, eles podem ser assim enumerados: (i) o ato erótico não é intrinsecamente relacional ou colaborativo; (ii) ele é profundamente polarizador e hierárquico: ele efetivamente divide, classifica e distribui seus participantes em duas categorias distintas e radicalmente opostas: o papel ativo e o papel passivo; (iii) ele articula-se com a política, expressando as relações de poder, isto é, as categorias eróticas ativo e passivo são social e politicamente articuladas. (Halperin, 1990: 29-30) 
$\mathrm{Na}$ Atenas Clássica, o discurso público masculino tende a representar o ato erótico, primeiro, não como um ato coletivo compartilhado, uma conjugalidade, mas como uma ação praticada por uma pessoa sobre outra. Ele não produz uma relação de mutualidade, mas um ato ou um impacto, de acordo com o ponto de vista do participante. Por isso, ele não possui um caráter intrinsecamente relacional ou colaborativo, mas unilateral, exclusivista e de dominação pessoal.

Segundo, precisamente porque ele é concebido como essencialmente centrado no gesto assimétrico da penetração fálica, o ato erótico é uma experiência profundamente polarizadora, dividindo, classificando e distribuindo seus participantes em categorias distintas e radicalmente opostas, quais sejam, o parceiro insertivo ou ativo e o parceiro receptivo ou passivo. Desde que o parceiro insertivo é interpretado como um agente erótico, cuja penetração fálica expressa 'atividade' erótica, ao passo que o parceiro receptivo é interpretado como um paciente erótico, cuja submissão à penetração fálica expressa 'passividade' erótica, o ato erótico também é hierárquico.

Finalmente, essa hierarquia expressa uma dominação sociopolítica. A relação entre os parceiros eróticos ativo e passivo reproduz a relação configurada entre superior e subordinado nas esferas social e política. Estabelece-se, destarte, uma isomorfia entre o papel erótico de um indivíduo e seu status sociopolítico. Isso implica em que um cidadão masculino adulto só pode ter relações eróticas legítimas com pessoas de status sociopolítico inferior, ou seja, mulheres, garotos, estrangeiros ou escravos. Um ato erótico reproduz o diferencial em status sociopolítico que distingue os parceiros envolvidos: a autoridade e o prestígio do cidadão masculino adulto expressam-se em seu privilégio erótico - em seu poder de iniciar um ato erótico, em seu direito de obter prazer por meio desse ato e na própria precedência do papel erótico insertivo.

Assim, para um contato erótico entre dois homens ser considerado legítimo e respeitável, as pessoas envolvidas não devem possuir o mesmo status sociopolítico. A relação erastés/erómenos, ou pederastia, deve incluir obrigatoriamente uma pessoa de status superior e uma de status inferior. Além disso, os atos eróticos nessa relação devem ser congruentes com o diferencial de poder de acordo com o qual a relação foi estruturada. Isso implica em que o parceiro superior tomava a precedência erótica somente ele poderia iniciar um ato erótico, penetrar o corpo de seu parceiro e obter prazer erótico. A falta de reciprocidade social na relação acarretava a falta de reciprocidade erótica, e ambas eram necessárias. Em sua análise, Halperin chega a uma conclusão muito importante, pois reveladora da interdependência cultural entre práticas sociais e experiências subjetivas:

Os autores gregos sugerem que as escolhas sexuais nem sempre expressam a essência individual de um agente ou revelam a orientação profunda da vida interna de uma pessoa, independentemente de sua vida política ou social. Pelo contrário, as identidades sexuais dos atenienses clássicos - as 
experiências de si próprios enquanto agentes sexuais e enquanto seres humanos possuidores de desejos - parecem ser inseparáveis de, se não determinadas por, suas posições públicas. (Halperin, 1990: 32-33)

Sendo assim, o sistema erótico dos atenienses clássicos não pode ser entendido se for descrito enquanto uma esfera autônoma da vida governada por leis internas próprias. Suas atitudes e práticas eróticas só revelam sua coerência sistemática se as situamos no amplo contexto social no qual elas estão mergulhadas, desde que a esfera erótica dos atenienses clássicos, longe de ser independente e estar separada da política, era constituída pelos mesmos princípios pelos quais se organizava a vida pública ateniense. (Halperin, 1990: 31)

Diferentemente do mundo moderno ocidental, no qual as categorias sexuais (homo-, hetero- e bissexualidade) são articuladas pela 'sexualidade', enquanto esfera ideologizante autônoma, e não se relacionando de forma tão direta com questões sociopolíticas, na Atenas Clássica, as categorias eróticas (ativo e passivo) são articuladas pelas relações de poder e não podem ser entendidas sem referência a essas relações.

Desse modo, podemos pensar as categorias ativo e passivo para os atenienses clássicos, não apenas enquanto categorias eróticas, mas enquanto categorias sócio-eróticas, pois elas exprimem uma posição erótica e uma posição na hierarquia sociopolítica. A cidadania para o homem ateniense, portanto, era um conceito (e uma experiência) sociopolítico simultaneamente articulado com o gênero e com a prática erótica de seu titular. (Halperin, 1990: 11)

A partir desses pontos, Halperin pôde estabelecer que na Atenas Clássica vigorava uma complexa estruturação que articulava estreita e intimamente a erótica e o poder político. Essa estruturação concede a exclusividade do direito à voz política e do acesso ao espaço público aos cidadãos atenienses em plena maturidade da atividade fálica (papel erótico insertivo). Esse direito e esse acesso são vetados aos outros membros da cidadania (mulheres e jovens) e aos outros membros da comunidade (escravos e estrangeiros), todos em submissão real ou potencial ao falo através da passividade (papel erótico receptivo). A articulação entre erótica e poder político plasma-se, assim, na polaridade ativo/passivo, o que faz identificar a masculinidade com a atividade fálica (o ato de penetrar quem quer que seja, do sexo masculino ou feminino) e considerar a passividade erótica voluntária, condição identificada com a inferioridade política, um ato de submissão indigno para o cidadão ateniense do sexo masculino, já que tal desejo representa o abandono voluntário de uma identidade masculina a favor de uma identidade feminina, violando o senso de congruência profundamente sentido e ansiosamente defendido no mundo grego, entre gênero, práticas eróticas e identidade social de uma pessoa. Portanto, essa cultura erótica masculina estabelece uma assimetria erótica estruturada por, e simultaneamente estruturante de, uma assimetria 
sociopolítica. O comportamento erótico, muito mais que expressar inclinações ou disposições internas de alguém, servia para posicionar atores sociais nos lugares designados para eles na estrutura hierárquica da política e da sociedade ateniense.

Desse modo, o poder dessa cultura erótica masculina era posto em funcionamento através de um dispositivo complexo responsável por uma dupla dominação: uma dominação erótica configurada por uma dominação sociopolítica. E essa dominação constitui-se em torno do falo, não enquanto simplesmente pênis ou um mero equipamento da anatomia masculina, mas enquanto um símbolo do poder sociopolítico construído culturalmente pelo discurso erótico grego ${ }^{13}$.

\section{Conclusão}

A historiografia construcionista da erótica grega vincula-se claramente à Nova História Cultural. Seus historiadores "defendem e praticam a descrição da pluralidade dos objetos, dos métodos." (Reis, 2003: 76) Na análise que Reis faz do processo que vai da história global à história em migalhas, verifica-se a passagem da história-ciência social à história-literatura, o que pôde tornar o conhecimento histórico "mais flexível, mais qualitativo, mais poético, mais pessoal, mais imaginativo, mais livre. Libertou-se do rigor da ciência, que na verdade era um falso rigor". (Reis, 2003: 94) Uma das técnicas fundamentais do método criado pelos autores construcionistas, a Poética Cultural do Desejo, é retirada do arsenal metodológico da crítica literária:

Críticos literários, pesquisando o campo da produção literária, descrevem as estratégias artísticas dominantes (e contra-dominantes), combinando e ordenando elementos literários para construir vários tipos, ou gêneros, de trabalhos literários. Alguns críticos culturais estão agora usando técnicas análogas para descrever os procedimentos por meio dos quais formas significativas de experiência coletiva são socialmente construídas, muitas vezes através de uma reconstituição de componentes herdados. (Halperin; Winkler; Zeitlin, 1990: 4)

Também, reflete-se nesta historiografia as mudanças que estão deslocando e fragmentado as identidades, que estão colocando em colapso a estabilidade, a fixidez e

\footnotetext{
${ }^{13}$ Halperin, 1990, capítulo 1, nota 83, chama o discurso erótico grego de fálico porque “(1) os contatos sexuais são polarizados em torno da ação fálica, isto é, são definidos por quem tem o falo e pelo que é feito com ele; (2) prazeres sexuais que não sejam prazeres fálicos não contam na categorização de contatos sexuais; (3) para qualificar um contato de sexual, requer-se que um - e não mais do que um dos dois parceiros tenha um falo".
} 
a unicidade da relação moderna entre sujeito e estrutura ${ }^{14}$, o que se traduz na recusa da metafísica, da história filosófica tradicional, na crença "na possibilidade de uma observação eficaz de qualquer objeto em escala micro" (Reis, 2003: 92), na consideração do olhar global como totalitário e ameaçador das liberdades individuais, na crença de "que a intervenção na sociedade deva ser localizada e pontual, sem pretensões de mudanças revolucionárias globais" (Reis, 2003: 92), o que Reis pondera como sendo a "passagem do todo (holismo) ao tudo (micro)" (Reis, 2003: 92). Na introdução de Before Sexuality, Zeitlin diz:

Descrito assim, o projeto pode soar muito ambicioso, talvez mesmo presunçoso, e então nos apressamos em negar qualquer pretensão a praticar alguma ciência universal da humanidade. Realmente, tendemos a estar desconfiados de reivindicações a ver e compreender o inteiro, qualquer inteiro; será suficiente o bastante se formos capazes de iluminar partes ou aspectos de nossa matéria em estudo. Este volume, então, não aspira prover uma pesquisa abrangente do sexo grego antigo, muito menos da sexualidade. Os esboços que ele contém são admitidamente pluralistas, parciais e descontínuos - uma série de vislumbres como que flagrados através de diferentes vigias postados nas paredes ao redor do canteiro de uma grande construção. Vindos de diferentes direções, mas trabalhando juntos, esperamos fornecer uma série de relatos em andamento sobre alguns dos mais importantes meios - religioso, social, político, filosófico, médico, literário e artístico - nos quais a experiência sexual foi construída e refletida pelos povos falantes da língua grega que viviam ao redor da bacia mediterrânica dos tempos arcaicos até o Império Romano. (Halperin; Winkler; Zeitlin, 1990: 4-5)

Verifica-se, ainda, na análise de Reis, a passagem do material ao imaginário, ao simbólico, isto é, a valorização do mundo psicológico, íntimo, dos indivíduos e coletividades, das crenças e superstições, medos e fantasias, sonhos e pesadelos. (Reis, 2003: 93)

A emergência do sujeito pós-moderno que se corporifica a partir da desenfreada fragmentação das identidades na nova realidade instaurada pela segunda metade do século XX guia Winkler em sua antropologia cultural do sexo e do gênero na Grécia Antiga. A Crítica Feminista condiciona a sua preocupação em desmistificar os discursos masculinos gregos cristalizados nos protocolos androcêntricos da cultura grega.

Afloram na análise de Halperin as emergências das questões pungentes ligadas às multiplicações, as diversificações, as contradições identitárias postas pelos

${ }^{14}$ Cf. Hall, 2006, A identidade em questão, p. 7-22. 
desdobramentos, pelos deslocamentos sociais promovidos pela Modernidade tardia (ou, se preferirem, pela pós-Modernidade).

Em termos de manifestações identitárias eróticas, "em uma época em que as fortes tentações da história identitária correm o risco de embaralhar toda distinção entre um saber controlado, universalmente aceitável, e as reconstruções míticas que vêm confirmar memórias e aspirações particulares" (Chartier, 2002: 15), a interpretação de Boswell sofre do mesmo mal que nos alerta Eric J. Hobsbawn em relação às comunidades imaginárias:

\begin{abstract}
A projeção no passado de desejos do tempo presente ou, em termos técnicos, o anacronismo, é a técnica mais corrente e mais cômoda para criar uma história própria a satisfazer as necessidades de coletivos ou de 'comunidades imaginárias' - conforme a expressão de Benedict Anderson - que estão longe de serem exclusivamente nacionais. (Hobsbawn apud Chartier, 2002: 15)
\end{abstract}

Se John Boswell pretendia ainda a clareza da estrutura, o distinto universal, a essência da identidade, valores típicos do pensamento moderno, Halperin ocupa-se com as múltiplas e complexas manifestações identitárias. Ele retorna ao mito do Aristófanes platônico com outras perguntas, com o olhar iluminado por outras questões que só a pressão dos deslocamentos do sujeito pós-moderno poderia proporcionar.

\title{
Referências Bibliográficas
}

AESCHINES. Against Timarchus. Cambridge \& London: Harvard University Press \& William Heinemann Ltd., 1988.

BARBO, Daniel. Detratores do homoerotismo grego: uma historiografia essencialista. História da historiografia, Ouro Preto, número 6, março, 2011, 171-188.

BARBO, Daniel. Michel Foucault e a Historiografia Construcionista. E-hum, Belo Horizonte, Editora uniBH. Vol.4, N. 2, 2011, 21-41.

BARBO, Daniel. O Triunfo do Falo: Homoerotismo, Dominação, Ética e Política na Atenas Clássica. Rio de Janeiro: E-Papers, 2008.

BOSWELL, John. Christianity, social tolerance and homosexuality: gay people in western Europe from the beginning of the Christian Era to the fourteenth century. Chicago and London: The University of Chicago Press, 1980.

BOSWELL, John. Same-sex unions in premodern Europe. New York: Vintage Books, 1994.

BURKE, Peter. O que é História Cultural? Rio de Janeiro: Zahar, 2005.

Revista Heródoto. Unifesp. Guarulhos, v. 01, n. 01. Março, 2016. p. 231-264 
CHARTIER, Roger. À beira da falésia: a história entre certezas e inquietude. Porto Alegre: Ed. Universidade/UFRGS, 2002.

DOVER, K. J. Review: Greek Sexual Choices. Reviewed work: One Hundred Years of Homosexuality and Other Essays on Greek Love by David M. Halperin. The Classical Review, New Series, Vol. 41, No 1, (1991), pp. 161-162.

FOUCAULT, Michel. História da sexualidade: a vontade de saber. $13^{a}$ edição, Rio de Janeiro: Graal, 1988.

FOUCAULT, Michel. História da sexualidade: o uso dos prazeres. Rio de Janeiro: Graal, 1984.

FOUCAULT, Michel. História da sexualidade: o cuidado de si. Rio de Janeiro: Graal, 1985.

FREUD, Sigmund. A Interpretação dos Sonhos. Rio de Janeiro: Imago, 2001.

GINZBURG, Carlo. O fio e os rastros. São Paulo: Companhia das Letras, 2007.

GOLDHILL, Simon. [untitled] Reviewed work: Before Sexuality: The construction of Erotic Experience in the Ancient Greek World by David M. Halperin; John J. Winkler; Froma I. Zeitlin. The Classical Review, New Series, Vol. 41, No 1, (1991), pp. 159-161.

HALL, Stuart. A identidade cultural na pós-modernidade. 11 a ed., Rio de Janeiro: DP\&A, 2006.

HALPERIN, David M. One hundred years of homosexuality and other essays on Greek love. New York, London: Routledge, 1990.

HALPERIN, David M.; WINKLER, John J.; ZEITLIN, Froma I. Before sexuality: the construction of erotic experience in the Greek world. Princeton: Princeton University Press, 1990.

KOSELLECK, Reinhart. Futuro passado: contribuição à análise dos tempos históricos. Rio de Janeiro: Contraponto: Ed. Puc-Rio, 2006.

LAIPSON, Peter. Review: From Boudoir to Bookstore: Writing the History of Sexuality. A Review Article. Reviewed Work: One Hundred Years of Homosexuality by David M. Halperin, Making Sex by Thomas Laqueur, Passion and Power by Kathy Peiss; Christina Simmons; Robert A. Padgug, Romantic Longings by Steven Seidman. Comparative Studies in Society and History, Vol. 34, no 4, (Oct., 1992), pp. 636-644.

REIS, José Carlos. História \& Teoria: Historicismo, Modernidade, Temporalidade e Verdade. Rio de Janeiro: Editora FGV, 2003. 
SUTTON Jr., Robert F. [untitled] Reviewed works: Before Sexuality: The construction of Erotic Experience in the Ancient Greek World by David M. Halperin; John J. Winkler; Froma I. Zeitlin; One Hundred Years of Homosexuality and Other Essays on Greek Love by David M. Halperin; The Constraints of Desire: The Anthropology of Sex and Gender in Ancient Greece by John J. Winkler. The Classical Journal, Vol. 87, $\mathrm{n}^{\mathrm{o}} 2$, (Dec., 1991 - Jan., 1992), pp. 189-191.

THORP, John. The Social Construction of Homosexuality. Phoenix, Vol. 46, n 1 , (Spring, 1992), pp. 54-61.

VERSTRAETE, Beert C. [untitled] Reviewed works: One Hundred Years of Homosexuality and Other Essays on Greek Love by David M. Halperin; The Constraints of Desire: The Anthropology of Sex and Gender in Ancient Greece by John J. Winkler; Before Sexuality: The construction of Erotic Experience in the Ancient Greek World by David M. Halperin; John J. Winkler; Froma I. Zeitlin. Journal of the History of Sexuality, Vol. 2, $\mathrm{n}^{\mathrm{o}}$ 2, Special Issue, Part 1: The State, Society, and the Regulation of Sexuality in Modern Europe, (Oct., 1991), pp. 289-293.

WINKLER, John J. Las coacciones del deseo: antropología del sexo y el género en La antigua Grecia. Buenos Aires: Manantial, 1994. 
